\title{
Evaluation measure of $3 d$ volumetry of masseter hypertrophy: association with modalities of imaging
}

\author{
Avaliação de medidas volumétricas 3D da hipertrofia massetérica \\ em dois casos: associação com modalidades de imagem
}

\author{
Antonione Santos Bezerra PINTO ${ }^{1}$ iD 0000-0002-6577-2816 \\ Neiandro dos Santos GALVÃO2 ID 0000-0001-6054-9431 \\ Jean de Pinho MENDES ${ }^{3}$ iD 0000-0002-6811-9548 \\ Paulo Henrique Viana PINTO $^{3}$ iD 0000-0003-0945-9566
}

Sérgio Lúcio Pereira de Castro LOPES ${ }^{4}$ iD 0000-0002-0882-5862

André Luiz Ferreira COSTA ${ }^{5}$ iD 0000-0003-4856-5417

\begin{abstract}
Masseteric hypertrophy is a benign condition, asymptomatic and rare, characterized by the excessive development of the masseter muscle, which usually results in aesthetic complaints. The imaging exams for differential diagnosis of pathologies in the parotidmasseteric region is always recommended. This work aims the imaging characterization of masseteric hypertrophy through the report of two clinical cases combining different imaging modalities: panoramic radiography, magnetic resonance imaging, computed tomography, ultrasonography and 3D volumetry. Two male subjects with no family history of masseteric hypertrophy were referred to a diagnostic center in dentomaxillofacial radiology due to an increase in bilateral facial volume in the masseteric region. Images of the panoramic radiography showed an increase of the bilateral mandibular angle in both cases. Using computerized tomography, bilateral masseter muscle hypertrophy was demonstrated in the patients, and magnetic resonance scan and ultrasound examination were performed for better visualization and muscle measurement. 3D volumetry assessment of musculature showed as additional tool to evaluate the status of the masseter muscles in patients with Masseteric hypertrophy. Therefore, the association of imaging examinations allowed to perform the imaging characterization of masseteric hypertrophy with presence of bone exostosis.
\end{abstract}

Indexing terms: Diagnostic imaging. Hypertrophy. Masseter muscle. Radiology.

\section{RESUMO}

A hipertrofia massetérica é uma condição benigna, assintomática e rara, caracterizada pelo desenvolvimento excessivo do músculo masseter, que geralmente resulta em queixas estéticas. São sempre recomendados os exames de imagem para diagnóstico diferencial

$\boldsymbol{\nabla \nabla} \boldsymbol{\nabla}$

1 Universidade Federal do Ceará, Departamento de Morfologia. Rua Delmiro de Farias, s/n., Rodolfo Teófilo, 60430-170, Fortaleza, CE, Brasil. Brasil. Correspondência para / Correspondence to: ASB PINTO. E-mail: <antonione182@hotmail.com>.

2 Universidade Estadual de Campinas, Faculdade de Odontologia. Piracicaba, SP, Brasil.

3 Universidade Estadual do Piauí, Faculdade de Odontologia. Parnaíba, PI, Brasil.

${ }^{4}$ Universidade Estadual Paulista - UNESP, Instituto de Ciência e Tecnologia, Departamento de Diagnóstico e Cirurgia. São José dos Campos, SP, Brasil.

${ }^{5}$ Universidade Cidade de São Paulo, Departamento de Ortodontia e Radiologia. São Paulo, SP, Brasil.

$\mathbf{v} \mathbf{v}$

Como citar estar artigo / How to cite this article

Pinto ASP, Galvão NS, Mendes JP, Pinto PHV, Lopes SLPC, Costa ALF. Evaluation measure of 3d volumetry of masseter hypertrophy: association with modalities of imaging. RGO, Rev Gaúch Odontol. 2018;66(4):375-383. http://dx.doi.org/10.1590/1981-8637201800040000123484 
de patologias na região parotídea-massetérica. Neste trabalho objetiva-se a caracterização da imagem da hipertrofia massetérica através do relato de dois casos clínicos combinando diferentes modalidades de imagem: radiografia panorâmica, ressonância magnética, tomografia computadorizada, ultra-sonografia e volumetria 3D. Dois indivíduos do sexo masculino sem história familiar de hipertrofia massetérica foram encaminhados para um centro de diagnóstico em radiologia dentomaxilofacial devido ao aumento do volume facial bilateral na região massetérica. As imagens da radiografia panorâmica mostraram um aumento do ângulo mandibular bilateral em ambos os casos. Usando tomografia computadorizada, foi demonstrada hipertrofia muscular massetérica bilateral nos pacientes, e a varredura de ressonância magnética e ultra-sonografia foram realizadas para melhor visualização e medição. A avaliação volumétrica em 3D da musculatura mostrou-se como ferramenta adicional para avaliar o estado dos músculos masseteros em pacientes com hipertrofia massetérica. Portanto, a associação de exames de imagem permitiu realizar a caracterização da imagem da hipertrofia massetérica com presença de exostose óssea.

Termo de indexação: Diagnóstico por imagem. Hipertrofia. Músculo masseter. Radiologia.

\section{INTRODUCTION}

Masseter hypertrophy $(\mathrm{MH})$ is a rare benign condition of excessive development of the masseter muscles (MM), either unilaterally or bilaterally, being often asymptomatic, but resulting in aesthetical complaints and more rarely in functional problems [1]. In the majority of the cases its origin is idiopathic, but can be associated with multiple factors, mostly related to hyperfunctional muscle habits and masticatory overload. Among these, one can cite occlusal problems such as tooth missing, temporomandibular joint disorders, psychological factors and para-functional habits (e.g. bruxism and teethclenching) $[1,2]$.

These factors seem to account for the increase in neuromuscular stimulus and consequent individual accession of muscle fibres, which are involved in the hypertrophy of the masseter muscle and would result in the widening of the mandibular angle - a region corresponding to its insertion. In general, aesthetical complaint is reported in cases of $\mathrm{MH}$ during puberty, ranging between the second and fourth decades of life, with no gender predominance [1-3].

The diagnosis of $\mathrm{MH}$ is achieved by means of clinical and imaging examinations. Clinically, by palpating the region of the ramus and mandibular angle, one can feel the hyper-tonicity of the masseter, mainly when the patient is in forced occlusion. In these cases, the visual aspect of the face is important as well. Imaging plays a critical role in analysing $\mathrm{MH}$ [2]. As for the imaging examination, the practitioner seeks to perform a differential diagnosis between possible inflammatory pathologies and involvement of bone, glands and soft tissue in the parotid-masseter region. Therefore, images of panoramic radiography (PR) and computed tomography (CT) allow the study of mandibular angle and ramus as well as visualisation of the presence or not of a bone spur. On the other hand, magnetic resonance imaging (MRI) and ultrasound (US) allow a more precise assessment of the masseter muscle $[1,4,5]$.

Treatment of $\mathrm{MH}$ is elective and depends on the type of the case (i.e. type I = visible palpable hypertrophy in forced occlusion only; type $\|$ = visible hypertrophy with prominent mandibular angle; or type III = visible hypertrophy with mandibular angle exostosis), as reported by Giudice et al. [6]. In this manner, a surgical approach for bone and/or muscle resection may be considered. Less invasive therapeutic procedures correspond to treatment alternatives. Use of type-A botulinum toxin, restorative/ rehabilitation procedures for correction of occlusal disorders, use of tranquiliser and myo-relaxing drugs, including manufacturing of occlusal splints, can also be considered [1-7].

Therefore, this article aims to perform the 3D image volumetry of $\mathrm{MH}$ by reporting two cases in which clinical examination was associated with different image modalities (i.e. PR, CT, MRI and US).

\section{CASE REPORTS}

Two male patients were referred to a general practice for radiographic examination in order to evaluate an increased facial volume in the masseter muscle region.

\section{Case 1}

An asymptomatic 15-year-old patient reported that after completing 14 years he noticed that his face was increasing in size. Clinical examination showed a bilateral soft-tissue mass on the left and right bodies near the mandibular angle, which became more evident when the patient was in habitual maximum intercuspation (figure 1). 


\section{Case 2}

An asymptomatic 19-year-old patient was referred for clinical evaluation because of a complaint of increase in the facial volume, but he did not know when it had begun. Clinical examination showed neither para-functional habit nor bilateral soft-tissue mass on the left and right bodies near the mandibular angle, which were more evident when the patient was in habitual maximum intercuspation (figure 1).

Both patients reported no similar cases in their families or history of trauma, paresthesia, trismus, dysphagia, mastication difficulties, speech difficulties, midline deviation, temporomandibular changes and infection. The main complaint of the two patients was related to aesthetics. The mouth opening of both patients, who had complete dentition, was $52.0 \mathrm{~mm}$. Extra-oral examination showed a marked increase in the volume of the masseter muscle bilaterally, but which was more prominent in the right side in both cases.

According to Giudice et al. [6], $\mathrm{MH}$ can be classified into three types. Type I is when the hypertrophy is palpable and visible in forced occlusion only; type II is when the hypertrophy is visible and the mandibular angle is prominent; and type III is when the hypertrophy is visible and there is exostosis in the mandibular angle. Our both cases correspond to type III.

As for the treatments, we have proposed elimination of para-functional habits and corrective surgery for patient 1 and only corrective surgery for patient 2 .

\section{Imaging assessment}

Next, the imaging examinations based on the different imaging modalities regarding both cases will be described in order to compare and characterise the $\mathrm{MH}$.

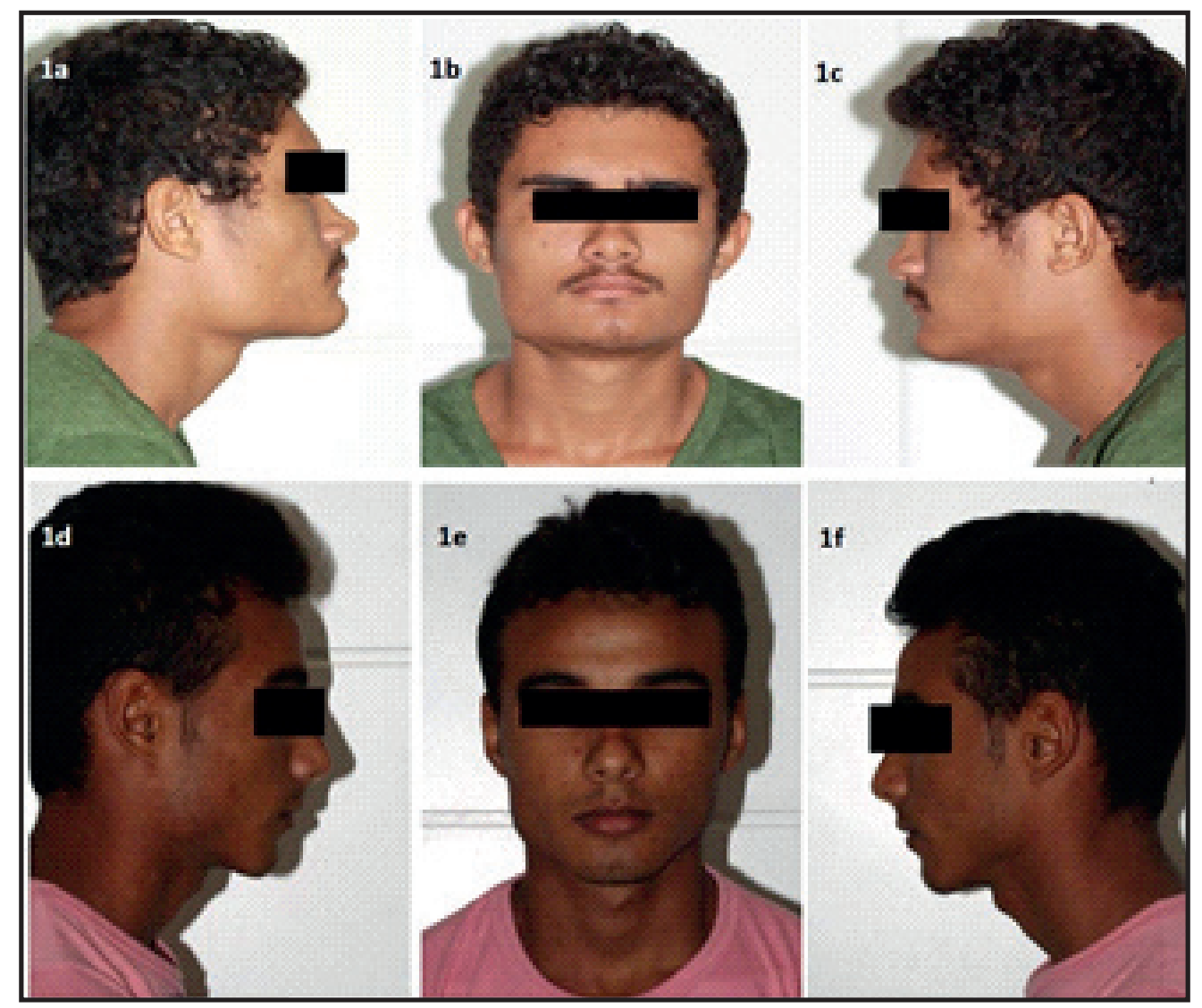

Figure 1. Case 1 - Clinical photographs of examination showing bilateral increase of soft tissue in the masseter region. (a) right lateral view; (b) frontal view; (c) left lateral view. Case 2 - Clinical photographs of examination showing bilateral increase of soft tissue in the masseter region. (d) right lateral view; (e) frontal view; (f) left lateral view. 
PR

The panoramic radiographs was performed by using OP-300' ${ }^{\text {TM }}$ device (Instrumentarium, Helsinki, Finland) of patient 1 and patient 2 show an increase in their mandibular angle on the left and right sides (figure 2).

\section{CT}

This examination was performed by using a multislice CT scanner (Brilliance, Philips Electronics, Amsterdam, Netherlands) with axial and coronal slices of $2.00 \mathrm{~mm}$, soft- tissue window, 3D multiplanar reconstructions and without use of venous contrast. In both cases, bilateral hypertrophy of the masseter muscle was demonstrated.

The 3D computed tomographic reconstruction evidenced an increased bone volume in the mandibular angle on the left and right sides in the region of the masseter muscle insertion (figure 3 ). As for Case 1, the coronal tomographic slices showed occlusal wear of teeth \#36 and \#46, suggesting excessive mastication, teeth clenching, bruxism, malocclusion, emotional disturbance or para-functional habits.
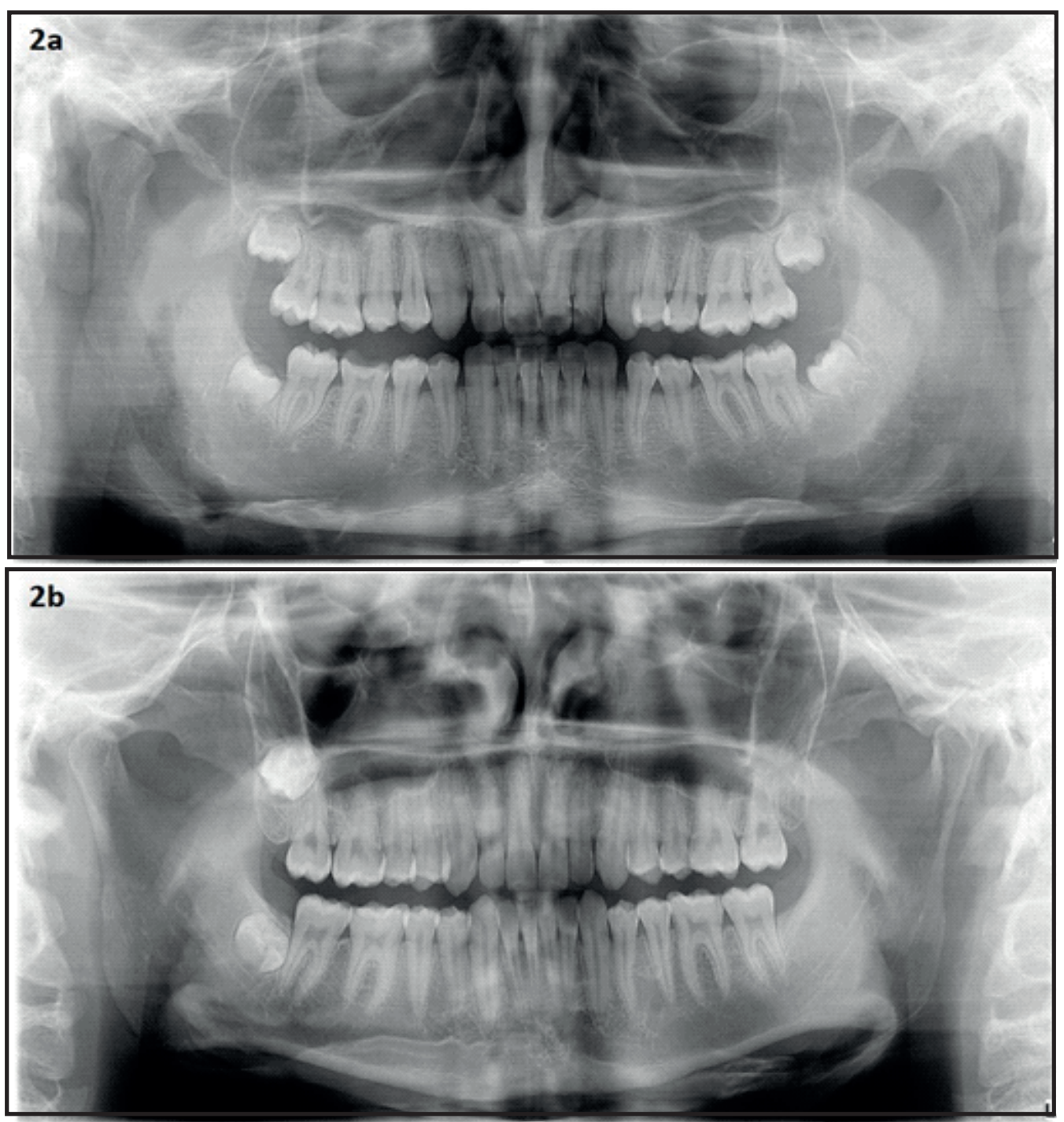

Figure 2. Case 1 - Panoramic radiograph. Note a bilateral increase in the mandibular angle and occlusal wear of teeth \#36 and \#46 (a). Case 2 - Panoramic radiograph. Note a bilateral increase in the mandibular angle (b) 

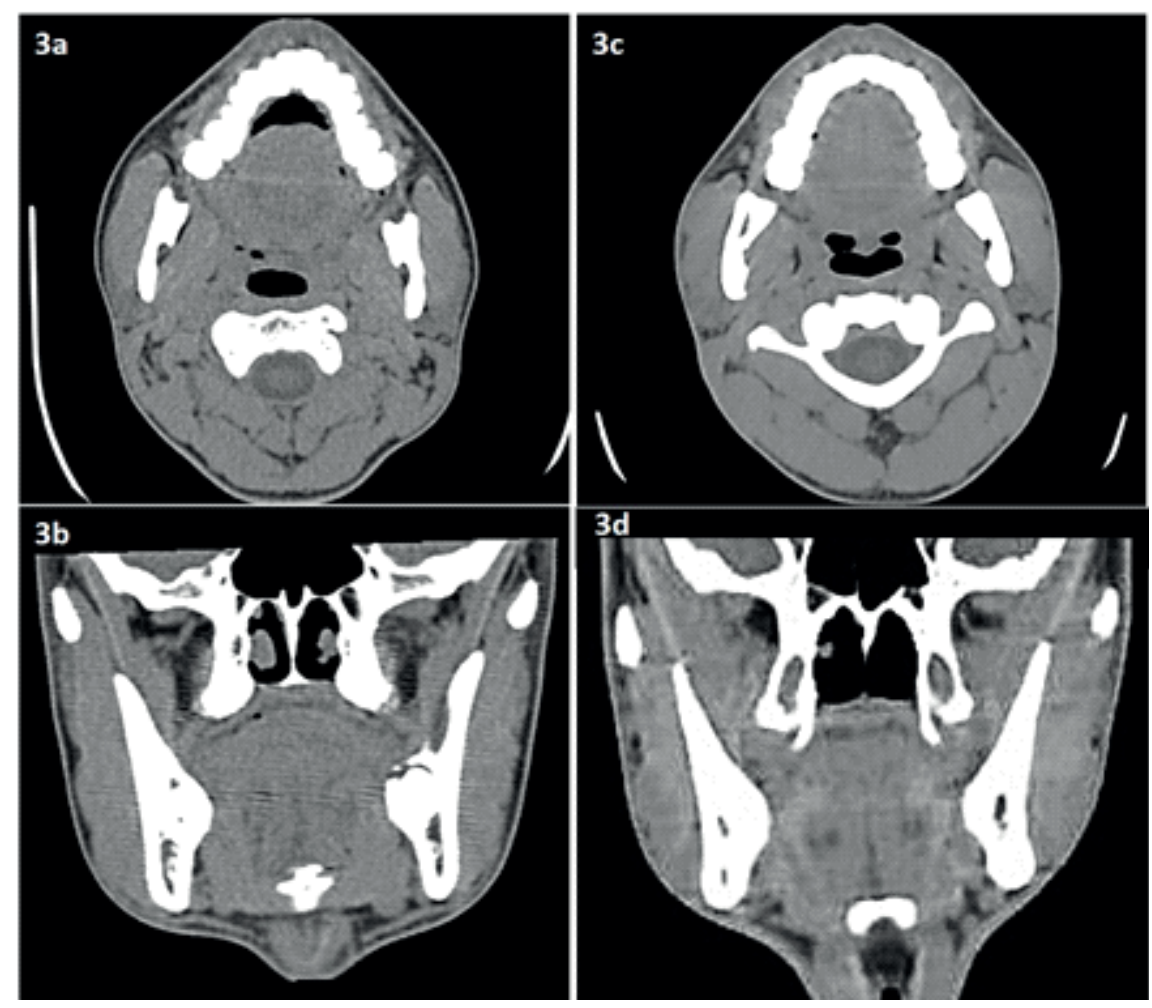

Figure 3. Computed tomograph showing bilateral hypertrophy of the masseter muscle - Case $1(a, b)$ and case $2(c, d)$ in axial and coronal view.

\section{Quantitative analysis}

\section{Case 1}

Measurement protocol (figure 4a): - Height: measure at the greatest length of the masseter muscle in the inferior-superior direction; - Width: measure at the greatest length of the masseter muscle in the lateral-lateral direction; - Thickness: measure at the greatest length of the masseter muscle in the anterior-posterior direction.

\section{Case 2}

Measurement protocol (figure 4b): - Height: measure at the greatest length of the masseter muscle in the inferior-superior direction; Width: measure at the greatest length of the masseter muscle in the lateral-lateral direction; - Thickness: measure at the greatest length of the masseter muscle in the anterior-posterior direction.

\section{US}

This examination was performed bi-dimensionally by using an ultrasound scanner equipment (MEDISON, model MYSONO U5) operating at a broadband ranging from 5.0 to $12.0 \mathrm{MHz}$ for linear scanning (figure 5).

\begin{tabular}{|c|c|c|c|}
\hline $\begin{array}{c}\text { Region } \\
\text { Masseter muscle }\end{array}$ & $\begin{array}{l}\text { Height } \\
(\mathrm{mm})\end{array}$ & $\begin{array}{l}\text { Width } \\
(\mathrm{mm})\end{array}$ & $\begin{array}{l}\text { Thickness } \\
(\mathrm{mm})\end{array}$ \\
\hline Left masseter & $69.9 \mathrm{~mm}$ & $16.8 \mathrm{~mm}$ & $54.9 \mathrm{~mm}$ \\
\hline Right masseter & $76.02 \mathrm{~mm}$ & $17.8 \mathrm{~mm}$ & $59.2 \mathrm{~mm}$ \\
\hline \multicolumn{4}{|l|}{$4 b$} \\
\hline $\begin{array}{c}\text { Region } \\
\text { Masseter muscle }\end{array}$ & $\begin{array}{l}\text { Height } \\
(\mathrm{mm})\end{array}$ & $\begin{array}{l}\text { Width } \\
\text { (mm) }\end{array}$ & $\begin{array}{c}\text { Thickness } \\
(\mathrm{mm})\end{array}$ \\
\hline Left masseter & $68.5 \mathrm{~mm}$ & $15.4 \mathrm{~mm}$ & $42.9 \mathrm{~mm}$ \\
\hline Right masseter & $76.3 \mathrm{~mm}$ & $17.6 \mathrm{~mm}$ & $43.5 \mathrm{~mm}$ \\
\hline
\end{tabular}

Figure 4. Quantitative analysis. Case 1 (4a) and case 2 (4b). 

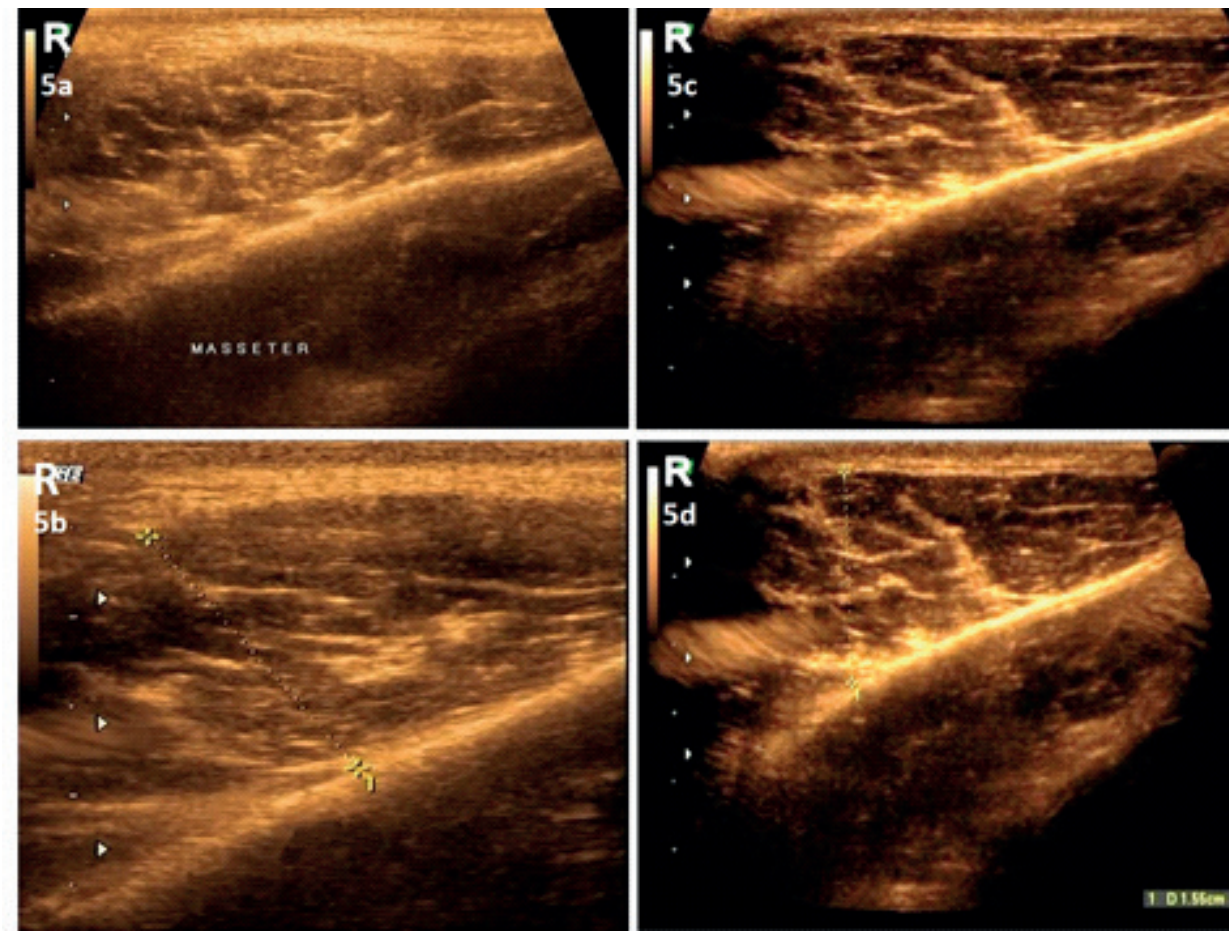

Figure 5. Case $1(\mathrm{a}, \mathrm{b})$ - Measurements of $1.56 \mathrm{~cm}$ (right side) and $0.98 \mathrm{~cm}$ (left side) regarding the anterior-posterior diameter in the region of mandibular ramus. Case $2(\mathrm{c}, \mathrm{d})$ - Measurements of $1.55 \mathrm{~cm}$ (right side) and $0.86 \mathrm{~cm}$ (left side) regarding the anterior-posterior diameter in the region of mandibular ramus.

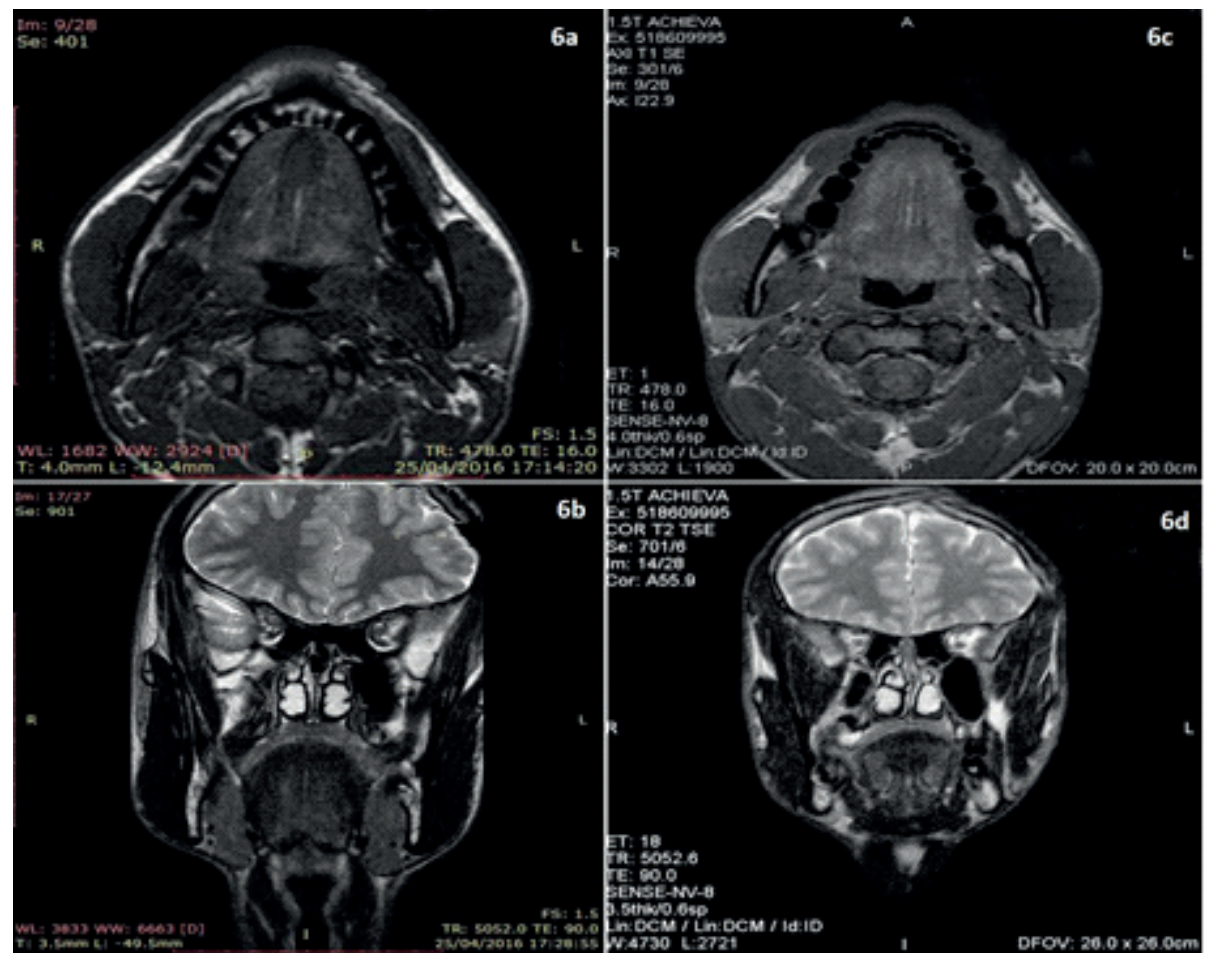

Figure 6. Magnetic resonance image of hypertrophy of the masseter muscle - Case $1(a, b)$ and case $2(c, d)$ in axial and coronal view. 
A volumetric increase was observed, with signs of hypertrophy of the muscular venter in both masseter muscles, mainly on the right side. The ultrasound examination of masseter muscles did not show any alteration suggesting pathology.

\section{MRI}

The MRI scan was performed using a 1.5 Tesla scanner (Sigma General Electric, Milwaukee, USA) with head coil for axial, coronal and sagittal anatomical planes. $\mathrm{T} 1$ and T2-weighted images were obtained with 8-channel head coil, phase matrix and T1 $(T R=478 \mathrm{~ms}$, isotropic voxel size of $0.72 \mathrm{~mm}, \mathrm{TE}=16 \mathrm{~ms}$, FOV of $1.0 \times 21.0 \mathrm{~cm}$, slice gap $=2.0 \mathrm{~mm})$ and $\mathrm{T} 2(\mathrm{TR}=6.5 \mathrm{~ms}$, isotropic voxel size of $0.72 \mathrm{~mm}, \mathrm{TE}=90.0 \mathrm{~ms}$, FOV of $21.0 \times 21.0 \mathrm{~cm}$, slice gap $=2.0 \mathrm{~mm}$ ) sequences .

MRI confirmed the conclusions drawn from panoramic and CT images, showing hypertrophy of masseter muscles in both cases (figure 6).

\section{Image segmentation and 3D volume reconstruction}

We used MRIcro (MacCausland Center for Brain Imaging, Columbia, SC, USA) to transform the original format (DICOM) to ANALYSE. The data were transferred to ITK-SNAP 2.4.0 (Kitware, New York, USA) to segment the masseter manually (right and left sides individually) in the whole extension (i.e. inferior-superior and lateralmedial directions) before calculating the total volume (in voxel/ $/ \mathrm{mm}^{3}$ ) (figure 7). For this step, only T1-images were used as these allow a better visualisation of the muscle. The entire segmentation process was performed by using a pen coupled to a digitising tablet (Intuos 2 model, Wacon, Otone, Saitama, Japan) in order to make disk delimitation the most reliable as possible. The muscle volumes of the two patients were compared to six healthy control subjects.

\section{DISCUSSION}

$\mathrm{MH}$ is a rare benign condition in which there is an excessive development of the masseter muscles, generally being asymptomatic. Due to the increase in its volume, the patient reports not only an aesthetical discomfort, but also a preoccupation with the presence of pathologies in the parotideo-masseteric region, mainly malignant ones. In order to achieve a correct differential diagnosis, relieve the patient's fear and guide the treatment (if necessary), in general the dentist-surgeon should associate the clinical examination with different imaging modalities. US, CT and MRI have been used to detail the muscles of patients with $\mathrm{MH}[1,2]$.

It's aetiopathogeny is unclear, but when acquired, it is commonly associated with several factors involving para-functional habits and hypertrophy of the masseter
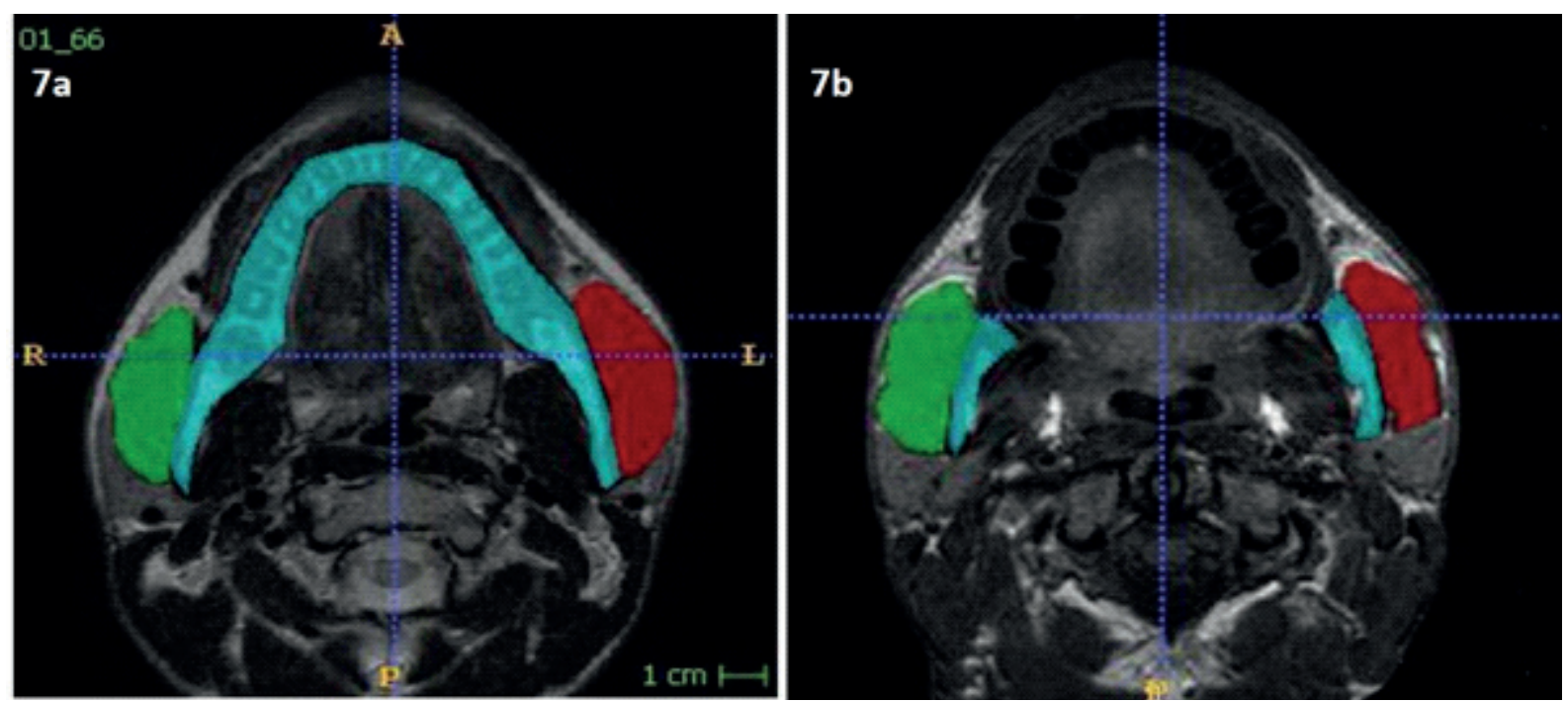

Figure 7. Image segmentation. Case 1 (7a) and case 2 (7b). 
muscle itself. In addition, when clinical examination shows no evidence of dental or stomatognathic characteristics explaining the pathology, some studies have suggested a congenital origin $[4,5]$. In the here-described cases, the patients reported neither similar cases in their families, nor temporomandibular joint problems or previous trauma. Panoramic radiography and 3D CT reconstruction showed presence of occlusal wear of teeth \#36 and \#46 in only one patient (Case 1), probably due to para-functional habits and occlusion problems (e.g. attrition, bruxism, clenching, anterior open bite). In the second case, the aetiopathogeny could not be determined (figure 3).

Despite the fact that $\mathrm{MH}$ affects both genders, the two cases above involved male patients aged between 15 and 19 years old, which is corroborated by the literature, since $\mathrm{MH}$ is more prevalent during the second and fourth decades of life. None of the patients presented pain or functional impairment despite the well-defined and visibly increased muscle mass, which was evidenced when the patients were in habitual maximum intercuspation (HMI). Moreover, the characteristic brachycephalic facial pattern (i.e. square-shaped face) was very visible in the two patients [2].

The diagnosis of $\mathrm{MH}$ is made based on the association of the patient's clinical aspects with imaging examinations. In this context, in order to achieve a clear and well-grounded differential diagnosis, the practitioner draws on PR, CT, MRI and/or US examinations, mainly when no dental or stomatognathic signs are found to explain such a condition, as in Case 2, In addition, studies like that by Benington et al. [2] demonstrated the use of the current imaging technologies and the possibility of quantifying the $\mathrm{MH}$ and its insertion sites [3].

In this sense, CT is indispensable in the case of masseter hypertrophy due to the high-quality images of bone structures, which is not possible with MRI because the cortical bone does not produce significant signals, it is extremely necessary to detect the presence or not of bone involvement, such as a bone spur (osseous hyperostosis), which corresponds to a basic finding in the case of $\mathrm{MH}$ [3]. Therefore, patients with major involvement of bone or muscle tissue are submitted to, respectively, osteotomy or partial resection, whereas the composite cases require reduction of muscle mass and osteotomy. In our case reports, on the other hand, MRI has facilitated the diagnosis of $\mathrm{MH}$ because the muscular structure produces more intense signs, thus making easier to compare the affected sides.

The use of CT allows simultaneous and detailed study of anatomical structures corresponding to the masseter muscle, especially regarding cross-sectional measurements. In this sense, US examinations can enrich the measurements. In addition, CT, MRI and US allowed visualisation and measurement of any asymmetry between the muscles of both patients [8].

However, Morse \& Brown [9] proposed that a panoramic radiograph or anterior-posterior projection of the mandible in association with US images of the masseter muscle and parotid gland is enough for diagnosis of HM, thus avoiding the need for more expensive and invasive procedures such as CT and sialography, respectively. Still, according to these authors, US has a major diagnostic value for measuring the cross-sectional dimension of the masseter muscle when relaxed. Moreover, the US examination of the masseter muscle should be performed simultaneously with that of the parotid glands in order to eliminate possible pathologies in the glandular region, since it allows to easily distinguish soft tissues, which is not always possible with CT [9].

In their studies, Benington et al. [2] used US to measure the masseter muscle. According to the latter author, even considering the measurement bias resulting from probing site and excessive pressure on the skin, the volume may still be over-estimated. However, US examination is useful for being non-invasive, rapid and free of risks/complications, mainly considering the inherent time-consuming operation of MRI and CT [2].

In our case reports, as also described by Fyfe et al. [3], the panoramic radiography evidenced the presence of more prominent mandibular angles (i.e. bone spurs) bilaterally, but MRI scans showed us the characteristics and relationship existing between soft tissues and bone in both patients, thus excluding the need for a more invasive intervention [3].

The use of US images in their study of facial muscles, including the masseter. According to the author, US images are not only efficient and accessible, but can also be applied for morphometric characterisation of objective parameters (i.e. thickness, volume, cross-sectional area and length) and dynamic evaluation of muscles [9]. Obtaining reference values allows variables to be compared, thus guiding the diagnosis and treatment of possible changes in the stomatognathic complex. 
In this way, one can observe in our case reports that the patients presented bilateral hypertrophy of masseter muscles as well as bilateral bone prominence compared to other studies in the literature. The combination between bone spur and muscle hypertrophy was a factor accounting for the square-shaped face, with this facial pattern being more associated with excessive bone development, since PR, CT and MRI scans showed strong evidence of an increase of bone tissue compared to US images.

3D volumetric analysis has been used to assess the degree of muscle in patients with unctional abnormalities of temporalis muscle. In fact, 3D volumetry appears to be useful for skeletal muscle mass determination in clinical settings. Therefore, quantification of hypertrophy size and volume by $3 \mathrm{D}$ volumetry could be a valuable surrogate end point letting the prediction of response to therapy.

After differential diagnosis by excluding other pathologies, the patients were informed about the masseter hypertrophy as well as about non-surgical and surgical therapeutic procedures for aesthetical-functional purposes, although they had opted for no intervention. After 1 year, the patients are feeling well, but the muscle has not reduced in size.

The combination of different imaging modalities has allowed the visualisation of the inter-relationship between bone and soft tissue structures, which is essential in the diagnosis and classification of both cases as being of type-III hypertrophy. 3D volumetry is poised to offer a comprehensive assessment of novel MH therapeutics.

\section{Collaborators}

ASB PINTO, design and conceptualization of the study, analysis and interpretation of the data, drafting and revising the manuscript. ASB PINTO and NS GALVÃO, drafting and revising the manuscript. JP MENDES and PHV PINTO, analysis and interpretation of the data. ASB PINTO, NS GALVÃO and
PHV PINTO, analysis and interpretation of the data. SLPC LOPES, acquisition, analysis and interpretation of the data. ALF COSTA, design and conceptualization of the study, analysis and interpretation of the data, drafting and revising the manuscrip.

\section{REFERENCES}

1. Andreadis D, Stylianou F, Link-Tsatsouli I, Markopoulos A. Masseter bilateral e hipertrofia do músculo pterigóideo interno: um desafio diagnóstico. Med Princ Prática. 2014;23(3):286-8. http://dx.doi.org/10.1159 / 000354099

2. Benington PC, Gardener JE, Hunt NP. Masseter muscle volume measured using ultrasonography and its relationship with facial morphology. Eur J Orthod. 1999;21(6):659-70.

3. Fyfe EC, Kabala J, Guest PG. Magnetic resonance imaging in the diagnosis of asymmetrical bilateral masseteric hypertrophy. Dentomaxillofac Radiol. 2014;28(1):52-54. https://doi.org/10. 1038/sj.dmfr.4600394

4. Mandel L, Kaynar A. Masseteric hypertrophy. N Y State Dent J. 1994;60(7):44-47.

5. Mandel L, Tharakan M. Tratamento da hipertrofia massetérica unilateral com toxina botulínica: relato de caso. J Oral Maxillofac Surg. 1999;57(8):1017-9. https://doi.org/10.1016/ S0278-2391(99)90029-0

6. Giudice M, Marra A, Barba A, Passariello N, D’Onofrio F. Hypertrophy of the masseter: a rare case associated with hypertrophic cardiomyopathy. Minerva Stomatol. 1992 Nov;41(11):535-42.

7. Bae JH, Choi DY, Lee JG, Seo KK, Tansatit T, Kim HJ. O músculo risório: considerações anatômicas com referência à injeção de neurotoxina botulínica para hipertrofia massetérica. Dermatol Surg. 2014;40(12):1334-9. https://doi.org/10.1097 / DSS.0000000000000223

8. Newton JP, Cowpe JG, McClure IJ, Delday MI, Maltin CA. Masseteric hypertrophy?: preliminary report. $\mathrm{Br} J$ Oral Maxillofac Surg. 1999;37(5):405-408. https://doi.org/10.1054 / bjom. 1999.0075

9. Morse $\mathrm{MH}$, Brown EF. Ultrasonic diagnosis of masseteric hypertrophy. Dentomaxillofac Radiol. 1990;19(1):18-20. https:// doi. org/10.1259/dmfr.19.1.2201578

Received on:18/5/2018 Final version resubmitted on: 23/7/2018 Approved on: 4/9/2018 